\title{
ECONOMICS OF IMPROVED AND LOCAL VARIETIES OF CASSAVA AMONG FARMERS IN OYO STATE, NIGERIA
}

\author{
MUHAMMAD-LAWAL, A., 1 *SALAU, S.A., ${ }^{2}$ and AJAYI, S.A. ${ }^{1}$
}

DOI: $\underline{\text { http://dx.doi.org/10.4314/ejesm.v5i2.10 }}$

Received 13th February 2012; accepted 2nd April 2012

\begin{abstract}
This study was based on the economics of improved and local cassava varieties and its welfare effect on producing farmers in Oyo State, Nigeria. A three-stage sampling procedure was used to collect information from 144 cassava farmers in the study area. However, only 120 pieces of questionnaires were retrieved and analyzed. Descriptive statistics, Gross Margin and Multiple Regression Analysis were the analytical tools employed for the study. The results of the study showed that a typical household comprised of 8 persons and the farmers were on the average 45.3 years of age. The profitability analysis revealed a Gross Farm Income (GFI) per hectare of $\$ 167,733$ and $\$ 114,569$ for improved and local varieties of cassava respectively. Multiple regression model was used to determine the factors influencing the output of cassava in the area. The result showed that farm size, age of the farmer and household size are the variables explaining the variation in output of cassava in the study area. Implicitly, this result showed that in other to increase cassava production, policies that ensure that these farmers have access to land should be emphasized. Also, a policy targeted at encouraging reduction in household size should be put in place for cassava farmers in the study area.
\end{abstract}

Keywords: Cassava varieties, small scale farmers and adoption of improved technologies

\section{Introduction}

Cassava (manihot esculenta crantz) is a perennial, vegetatively propagated shrub, grown throughout the lowland tropics. African countries produce over 103 million metric tonnes cassava per annum with Nigeria accounting for approximately 35 million metric tons per annum (FAOSTAT, 2009). Nigeria has the largest harvest in the world; three times more than the production level in Brazil and almost double the production level in Thailand and Indonesia (FAO, 2007). IITA (2005) attributed the large harvest in Nigeria to rapid population growth, internal market demand, availability of high yielding improved varieties of cassava tuber, and increase hectrage of farm land allocated to cassava in the country.

Cassava can be a powerful tool to eradicate poverty in Africa. The cash income from cassava proves more egalitarian than the other major staples because of cassava's low cash input cost (Nweke, 2004). Compared with other major staples, cassava performs well across a wide ecological spectrum. It therefore benefits farmers across broader swath of ecological zones. Cassava is, likewise, less expensive to produce. It tolerates

1Department of Agricultural Economics and Farm Management

Faculty of Agriculture, University of Ilorin, Nigeria

${ }^{2}$ Department of Agricultural Economics and Extension Services,

College of Agriculture and Veterinary Medicine, Kwara State

University, Malete, Nigeria.

*Corresponding author email: talk2salaushehu@yahoo.com poor soil, adverse weather and pests and diseases more than other major staples (Nweke, 2004). The crop puts ready money and food in the very vulnerable segments of society. Cassava stores its harvestable portion underground until needed; it is therefore a classic food security crop. Various parts of cassava such as the leaves stem and roots are used for different purposes. The leaves are common vegetables among the Sierra Leoneans while the stem is used as planting material during cassava production. The root tuber which is the most desirable component is processed into various products like garri, cassava flour (lafun), fufu and tapioca. It is a rich source of industrial alcohol (ethanol) and starch. The export drive for the crop increased the demand for cassava and promoted its cultivation (CBN, 2004).

Traditionally, an average of three to five crops is often intercropped with cassava. The crops are selected on the basis of differences in growth habits and can be combined in either simple or complex mixtures. Cassava constitutes a major item in the crop combination of the most farmers and contributes significantly to total farm income in Nigeria (Bamire et al., 2004). This observation could offer reasons as to why the 
federal government of Nigeria launched the "Presidential Committee on Cassava Export Promotion" in 2001 with the aim of making cassava a major non-oil foreign exchange earner because of its comparative advantage in the country. Following this initiative, cassava production increased between 2000/2001 to 2005/2006 farming seasons.

In response to the renewed interest in cassava cultivation and entrepreneurship, several new varieties of cassava were recently introduced to farmers after several on-farms testing in several locations (IITA, 2005). Most recent releases such as TMS 50395 AND TMS 30572 were doing much better in farmers' fields than earlier release. The current policy direction of the Federal government of Nigeria has encouraged cassava development leading to a new orientation in the research-extension-farmers linkage. Asogwa et al. (2005) observed that the input expansion policy of government in the cassava industry through the provision of improved cassava varieties and improved processing technology led to efficient use of resources in cassava production in Nigeria. However, the level of adoption of the improved technologies is low, improper application of some of the technologies are also ripe among farmers (Oni 2003). Given the various cassava programmes and policies implemented over the years to raise farmers' efficiency and productivity in cassava production, it then becomes imperative to empirically analyze the costs and returns of local and improved varieties of cassava. This study describes the socio-economic characteristics of farmers, estimate the profitability of improved and local varieties of cassava and determine the major factors influencing cassava production among farmers in the study area.

\section{Methodology \\ Study Area}

This research work was carried out in Oyo State, Nigeria. Oyo State with a total of thirty three Local Government Areas (LGAs) has a population of 5,591,589 and total land area approximately 28,454 square kilometers (NPC 2006). The State is located in South West Nigeria, it is bounded in the South by Ogun State and in the North by Kwara State, in the West by the Republic of Benin while in the East, it is bounded by Osun State. The topography is mainly plain to slightly gentle rolling lands. The annual rainfall ranges between $1500 \mathrm{~mm}$ and $3000 \mathrm{~mm}$. The average daily temperature ranges between 250c (77.00f) and 350c (95.00f), almost throughout the year. The residents of the area are mostly farmers' traders' transporters and civil servant who are Yoruba and other tribes from various part of the country. The soil type in the area enhances the production of maize, cocoa, oil palm, kola nut, cassava and vegetables.

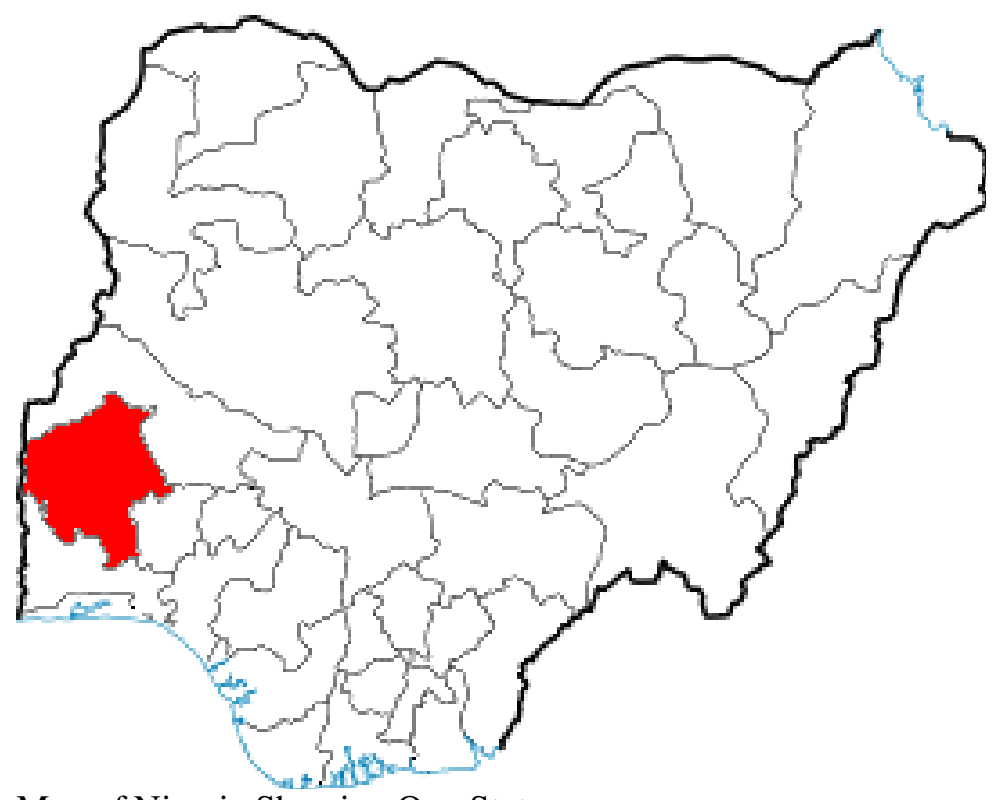

Map of Nigeria Showing Oyo State 


\section{Sampling Technique}

A three stage random sampling technique was used for this study. The first stage involves random selection of two local government areas of the thirty-three local government areas in Oyo State. The second stage was the random selection of six villages' each from the selected LGAs. The third stage was the random selection of twelve cassava farmers in the selected villages to make up a sample size of 144. However, only 120 questionnaires were returned and analyzed.

\section{Analytical Techniques}

In analyzing the data, descriptive statistics, Gross Margin analysis and multiple regression analysis are the analytical tools employed for the study. Gross Margin was used to determine the profitability of the enterprise. The gross margin (GM) is the difference between the gross farm income (GFI) and the total variable cost (TVC) incurred in cassava production. While the net margin is the difference between the gross margin and the total fixed cost (TFC)

\section{$\mathrm{GM}=\mathrm{GFI}-\mathrm{TVC}$}

Where;

$\mathrm{GM}=$ gross margin for the $\mathrm{i}^{\text {th }}$ variety GFI=gross farm income for the $i^{\text {th }}$ variety; $\quad \mathrm{TVC}=$ total variable cost for the $i^{\text {th }}$ variety

\section{$\mathrm{NFP}=\mathrm{GM}-\mathrm{TFC}$}

Where

$\mathrm{NFP}=$ net farm profit for the $\mathrm{i}^{\text {th }}$ variety; $\mathrm{TFC}=$ total fixed cost for the $\mathrm{i}^{\text {th }}$ variety.

The regression analysis was used to identify factors affecting the cassava production. The model is given below:

$Y=\beta_{0}+\beta_{1} X_{1}+\beta_{2} X_{2}+\beta_{3} X_{3}+\beta_{4} X_{4}+\beta_{5} X_{5}+\beta_{6} X_{6}+$ $\beta_{7} X_{7}+\beta_{8} X_{8}+\mu$

Where;

$\mathrm{X}_{1}=$ Land; $\mathrm{X}_{2}=$ Labour cost; $\mathrm{X}_{3}=$ Herbicide cost; $\mathrm{X}_{4}=$ Fertilizer cost; $\quad \mathrm{X}_{5}=$ Stem cutting cost; $\mathrm{X}_{6}=$ Variety; $\mathrm{X}_{7}=$ Age $; \mathrm{X}_{8}=$ Household size; $\mu=$ Error term.

\section{Results and Discussion}

The farmers' socio-economic characteristics are summarized in Table 1. About Ninety one percent and eighty percent of the farmers were male, against only 8 percent and 20 percent who are female for improved and local varieties respectively. The age of the farmers ranged between 30 and 69 years with an average of 45.3 years. This implies that the farmers are still in their active ages. The average year of experience was 19.9 years. This indicates that most farmers have been practicing farming for long. The accumulated years of experience may help farmers in crop selection and enable them to evolve the farming practices that are most suitable to their fragile environment. The average household size is 8 persons in the state. Most $(68.3 \%)$ households are polygamous in nature. Polygamous nature of the people probably explains the large family size recorded in the area. Household size is used as a proxy for labour because individual in the household is a potential source of labour. Their availability reduces labour constraints faced during the peak of the farming season (TeckleWorld et al., 2006). On the whole about $42.0 \%$ of the respondent farmers used both family and hired labour, $40.0 \%$ used hired labour and $18.0 \%$ used family labour in cassava production. This implies that most of the respondent farmers were involved in the labour in one way or the other. Cassava is the major calorie in the diet of rural consumers. Yields are low, production, harvesting and processing task are done manually and from households who consume most of the output farmers equally rely on each other for transfer of varieties which are more or less not improved (Nweke, 2004). Cassava is primarily produced and processed for sale as cash crop in urban areas and foreign markets. Production processing and marketing costs are reduced to enable Nigerian cassava to compete in the global starch markets and cassava pellets for livestock feeds. This help to generate income for farmers and industrialists. The fuels that drive the transformation include development and dissemination of high yielding varieties and the favourable government policies (Nweke, 2004). About 85 and 75 percent of the respondents are literate for improved and local varieties respectively. Given this level of literacy it is expected that information can be disseminated with ease among these households' heads. Basically, the levels of education of households' heads have significant impact on productivities, income earning opportunities and ability of farming households heads to effectively adopt better management practices.

It was observed that a high percentage of farmers neither used any of the herbicides because of lack of capital and high cost of herbicides. In Oyo State, the crop enjoyed a steady increase in 
importation both as a food and cash crop from 1960. It suffered attacks particularly by cassava mealybug in the last half of 1970s and early part of 1980s. This past attack problem was solved by the introduction of resistant varieties by the Oyo State Agricultural Development Agencies (OYSADA). As such, solid foundation for steady expansion in has been laid. The crop accounts for over $50 \%$ of food intake in Nigeria and provides substantial percentage food energy in the daily diet. Its demand as livestock feed and industrial raw material for production of alcohol and acetones, starches for textiles and pharmaceutical industries have been on the increase over the years (Kalu, 2003).

\section{Gross Margin Analysis}

The profitability analysis revealed a Gross Farm Income (GFI) of $\$ 167,733$ and $\$ 114,569$ for improved and local varieties of cassava respectively (Table 2.)

Table 2 Gross margin analysis per hectare of Improved and Local Varieties of Cassava

\begin{tabular}{|c|c|c|}
\hline Items & $\operatorname{Improved}(\AA)$ & $\operatorname{Local}(\mathbb{N})$ \\
\hline Gross farm income (GFI) & 116,733 & 114,569 \\
\hline Total variable cost (TVC) & 62,014 & 66,631 \\
\hline Total fixed cost (TFC) & 8,000 & 10,500 \\
\hline $\begin{array}{l}\text { Gross farm margin (GFI- } \\
\text { TVC) }\end{array}$ & 54,719 & 47,938 \\
\hline Net farm margin (GM-FC) & 46,719 & 37,438 \\
\hline$\%$ Gross farm income & 50.47 & 49.53 \\
\hline$\%$ Gross farm margin & 53.30 & 46.70 \\
\hline$\%$ Net farm profit & 55.51 & 44.48 \\
\hline
\end{tabular}

The table also showed a higher Net Farm Profit (NFP) $(55.51 \%)$ for improved than for local varieties of cassava. This result indicated that cultivation of improved variety is more profitable in the study area.

\section{Regression Analysis}

The results of the regression analysis are presented in Table 3.
Table 3 Estimate of Regression Analysis

\begin{tabular}{lcclc}
\hline Variables & & Coefficient & $\begin{array}{l}\text { Standard } \\
\text { Error }\end{array}$ & t- value \\
\hline Farm Size & $\left(\mathrm{X}_{1}\right)$ & & 11.5337 & 3.14 \\
& & $36.2194 * * *$ & & \\
Labour Cost & $\left(\mathrm{X}_{2}\right)$ & 0.3935 & 0.3782 & 1.04 \\
Herbicides Cost $\left(\mathrm{X}_{3}\right)$ & 5.3623 & 3.3594 & 1.60 \\
Fertilizer cost & $\left(\mathrm{X}_{4}\right)$ & -0.2715 & 0.2437 & -1.11 \\
Stem Cuttings & $\left(\mathrm{X}_{5}\right)$ & 1.0720 & 0.7602 & 1.41 \\
& & 0.3615 & 0.8754 & 0.41 \\
Variety & $\left(\mathrm{X}_{6}\right)$ & & & -1.84 \\
Age & $\left(\mathrm{X}_{7}\right)$ & $-0.4016^{*}$ & 0.2184 & -1.77 \\
Household Size & $\left(\mathrm{X}_{8}\right)$ & $-1.1993^{*}$ & 0.6783 & -1.51 \\
Constant & & -43.7941 & 29.0522 & \\
\hline
\end{tabular}

*, *** Coefficients are significant at $10 \%$ and $1 \%$ respectively.

Three out of the eight variables specified in the model are important in explaining the variation in cassava output in the study area. The coefficient of farm size is positive and significantly related to output at $1 \%$ level. This implies that as farm size increases, output of cassava also increases in the area. The coefficients of household size and age of the farmer are negative and significantly related to output at $10 \%$ level of probability. This implies that the older the farmer, the higher the output. The accumulated years of experience may help farmers in crop selection and enable them to evolve the farming practices that are most suitable to their fragile environment. The farmer's household size was negative which implies that the larger the farmers household size, the lower the probability of adopting improved cassava varieties by farmers and consequently the lower the output.

\section{Conclusion and Recommendations}

The production of cassava within the context of farming system and trade flows offers varying forms of employment to over $60 \%$ of the rural population in Nigeria. It is relatively high prominence in production because of ability to grow on poor/marginal soils and good yield has given it attention as being able to provide basic food in regions where people might otherwise starve or perish. It is thus a widely held belief that "there is no famine where cassava is grown" 
cassava is simply a "food security" crop. Thus, this study determines the profitability of improved and local varieties of cassava and also identifies factors that are important in determining the variation in cassava output. The profitability analysis revealed a Gross Farm Income (GFI) of $\$ 167,733$ and $\$ 114,569$ for improved and local varieties of cassava respectively. The result showed that farm size, age of the farmer and household size are the significant variables explaining the variation in output in the area. For increased productivity, policies that ensure that these farmers have access to land should be emphasized. Also, a policy targeting at household size reduction should be put in place for enhanced production in the study area.

\section{References}

Asogwa, B.C., Umeh, J.C. and Ingawa, S.A. (2005), Farm Management Dividends in a Friendly Policy Environment: The Case of Cassava Industry in Nigeria. In: Developing Entrepreneurship Abilities to Feed the World in a Sustainable Way. Proceedings of the 15th International Farm Management Association Congress and 5th Brazilian Rural Management Congress (IFMAABAR 2005), Campinas, Sao Paulo, Brazil, August 14 - 15, 2005, 24 pp.

Bamire, A. S., T. Alimi and A. B. Ayanwale (2004), Economic efficiency of land improvement Techniques among Cassava Farmers in the Wetlands of Nigeria. East Africa Journal of Rural Development, 20, 45-56.
CBN (2004), Annual report, Central Bank of Nigeria, Abuja.

FAOSTAT (2009), Online statistical Database. Rome Italy.website:www.fao.org.

FAO (2007) FAOSTAT Statistics Division of the food and collections. Subset=Agriculture. Agricultural Organization, http:/faostat.fao.org

IITA (2005), Report on new cassava varieties.

Kalu, B.A., 2003. Improving Benue State Economy on cassava production. A paper presented at the sensitization workshop on Cassava Production, Processing and Utilization, Makurdi, November, 24.

Nigerian Bureau of Statistics (NBS) (2006), The Nigerian statistical fact sheets on economic and social development, the National Bureau of Statistics, Abuja, 105 pp.

Nweke, F. (2004), New Challenges in the Cassava Transformation in Nigeria and Ghana. Environment and Production Technology Division (EPTD) Discussion Paper No. 118, International Food Policy Research Institute, Washington, D.C., USA, June, 2004, 118 pp.

Oni. S.A. (2003), "Estimating Supply vs. Response Via Producer Panel.

Teklewold, H., Dadi, L., Yami, A. and Dana, N., (2006), Determinants of adoption of poultry technology: a double hurdle approach, Livestock Research for Rural Development, 18(3), (http://www.cipav.org.co/lrrd//rrd18/3/tekl18040.htm) 
Table 1 Socio-economic characteristics of cassava farmers

\begin{tabular}{|c|c|c|c|c|}
\hline \multirow{2}{*}{$\begin{array}{l}\text { Characteristics } \\
\text { Sex of the Farmer }\end{array}$} & \multicolumn{2}{|c|}{$\begin{array}{l}\text { Improved Variety } \\
\text { Frequency } \%\end{array}$} & \multicolumn{2}{|c|}{$\begin{array}{l}\text { Local Variety } \\
\text { Frequency \% }\end{array}$} \\
\hline & & & & \\
\hline Male & 55 & 91.7 & 48 & 80 \\
\hline Female & 5 & 8.33 & 12 & 20 \\
\hline Total & 60 & 100.0 & 60 & 100 \\
\hline \multicolumn{5}{|l|}{ Age of the Farmer } \\
\hline $21-40$ years & 17 & 28.3 & 15 & 25.0 \\
\hline $41-60$ years & 40 & 66.7 & 24 & 40.0 \\
\hline $61-80$ years & 3 & 05.0 & 21 & 35.0 \\
\hline Total & 60 & 100.0 & 60 & 100.0 \\
\hline \multicolumn{5}{|l|}{ Education Status of the } \\
\hline Farmers & 14 & 23.3 & 25 & 41.7 \\
\hline No formal Education & 9 & 15.0 & 7 & 11.6 \\
\hline Primary Education & 16 & 26.7 & 10 & 16.6 \\
\hline Secondary Education & 16 & 26.7 & 10 & 16.7 \\
\hline Tertiary Education & 5 & 08.3 & 8 & 13.3 \\
\hline Adult Education & 60 & 100.0 & 60 & 100.0 \\
\hline \multicolumn{5}{|l|}{ Total } \\
\hline \multicolumn{5}{|c|}{ Marital Status of the Farmers } \\
\hline Married & 51 & 85.0 & 49 & 81.7 \\
\hline Single & 08 & 13.3 & 05 & 08.3 \\
\hline Widower/Separated & 01 & 01.7 & 06 & 10.0 \\
\hline Total & 60 & 100.0 & 60 & 100.0 \\
\hline \multicolumn{5}{|l|}{ Farming Experience } \\
\hline $1-10$ & 16 & 26.7 & 19 & 31.7 \\
\hline $11-20$ & 29 & 48.3 & 25 & 41.6 \\
\hline $21-30$ & 15 & 25.0 & 16 & 26.7 \\
\hline Total & 60 & 100.0 & 60 & 100.0 \\
\hline \multicolumn{5}{|l|}{ Household Size } \\
\hline 1- 5 & 15 & 25.0 & 12 & 20.0 \\
\hline 6- 10 & 35 & 58.3 & 36 & 60.0 \\
\hline $11-15$ & 10 & 16.7 & 12 & 20.0 \\
\hline Total & 60 & 100.0 & 60 & 100.0 \\
\hline
\end{tabular}

